\title{
Compartiendo el agua: conflictos (micro) políticos \\ en el acceso y distribución del agua. \\ El caso de la isla de Amantaní (Lago Titicaca, Perú)
}

\author{
Sharing water: micro political conflicts in the access and distribution of water. \\ The case of Amantani island (Lake Titicaca, Peru)
}

\author{
Susana Orellana-Gavidia \\ Pontificia Universidad Católica del Perú (PUCP). Lima, Perú. susanaorellana@gmail.com
}

Resumen - Este artículo examina la dinámica entre tres actores enfrentados, que utilizan tres discursos diferentes en su lucha, en la cual el objeto del conflicto es el agua. El caso de estudio es el de las comunidades de la isla de Amantaní, que se enfrentan a un cambio en la organización del sistema de gestión, abastecimiento y uso del agua para uso doméstico como resultado de la aprobación del proyecto Agua Para Todos que impulsa el gobierno central. En este contexto, la lucha entre estos actores se impone desde la posición de tradiciones dispares de derechos de agua ya que los comuneros usan el recurso bajo diferentes órdenes legales (el municipal, el de las comunidades campesinas y el de los sistemas de agua formales). El trabajo describe y analiza los procesos de negociación que tienen lugar, utilizando el concepto de Foucault de "programas de poder", que se refiere a que cada orden legal produce y reproduce discursos y acciones orientados para sus "formas" de ejercer el poder. El artículo argumenta que como resultado de estas luchas y confrontaciones, principalmente por medio de la retórica, se establece un nuevo mapa de distribución de los derechos de agua.

Abstract - This article examines the dynamic between three actors in confrontation that use three different discourses in their struggles, and where the object of the conflict is water. The case study are the communities of Amantani island that face a change in the organization of the management, supply and use of domestic water as a result of the implementation of the Project Water for All promoted by the national government. In this context, the struggle between these actors is waged from the standpoint of dissimilar traditions of water rights given that the comuneros (community members) use the resource under different legal orders (the municipal, the indigenous communities', and the formal water systems). The paper describes and analyses the negotiation processes that take place drawing on Foucault's concept of "programmes of power", which refers to the fact that legal orders produce and reproduce discourses and practices that are geared towards their "forms" of exercising power. The article argues that as a result of these struggles and confrontations, and mainly through rhetoric, a new map for the distribution of water rights is established.

Palabras clave: conflicto por el agua, órdenes legales plurales, derecho al agua, políticas públicas, Perú

Keywords: water conflict, plural legal orders, right to water, public policies, Perú

Información Artículo: Recibido: 10 octubre 2013

Revisado: 17 diciembre 2013

Aceptado: 15 enero 2014 